\title{
Environmental arsenic epidemiology in the Mekong river basin of Cambodia
}

\author{
Kongkea Phan ${ }^{\mathrm{a}, \mathrm{d}, *}$, Kyoung-Woong Kim ${ }^{\mathrm{b}}$, Jamal Hisham Hashim ${ }^{\mathrm{a}, \mathrm{c}}$ \\ a United Nations University-International Institute for Global Health (UNU-IIGH), UKM Medical Centre, 56000 Kuala Lumpur, Malaysia \\ ${ }^{\mathrm{b}}$ School of Environmental Science and Engineering, Gwangju Institute of Science and Technology, Gwangju 500-712, Republic of Korea \\ ${ }^{c}$ Department of Community Health, National University of Malaysia, UKM Medical Centre, 56000 Kuala Lumpur, Malaysia \\ ${ }^{\mathrm{d}}$ Research and Development Unit, Cambodian Chemical Society, Street 598, Phnom Penh, Cambodia
}

\section{A R T I C L E I N F O}

\section{Article history:}

Received 5 April 2014

Received in revised form

20 June 2014

Accepted 4 July 2014

\section{Keywords:}

Arsenicosis

Blood arsenic

Urinary arsenic

Serum albumin

Cambodia

\begin{abstract}
A B S T R A C T
We investigated relationship of arsenicosis symptoms with total blood arsenic (BAs) and serum albumin (SAlb) of residents in the Mekong River basin of Cambodia. We found that arsenicosis patients had significantly higher BAs and lower SAlb than asymptomatic villagers (Mann-Whitney $U$ test, $p<0.01$ ). Arsenicosis symptoms were found to be $76.4 \%$ (1.764 times) more likely to develop among individuals having an SAlb $\leq 44.3 \mathrm{~g} \mathrm{~L}^{-1}$ than among those who had an SAlb $>44.3 \mathrm{~g} \mathrm{~L}^{-1}(\mathrm{OR}=1.764,95 \% \mathrm{CI}=0.999$ 3.114 ) and $117.6 \%$ (2.176 times) as likely to occur among those with BAs $>5.73 \mu \mathrm{g} \mathrm{L}^{-1}$ than for those having BAs $\leq 5.73 \mu \mathrm{g} \mathrm{L}^{-1}(\mathrm{OR}=2.176,95 \% \mathrm{CI}=1.223-3.872)$. Furthermore, a significant negative correlation was also found between BAs and SAlb $\left(r_{\mathrm{s}}(199)=-0.354, p<0.0001\right)$. As such, this study suggests that people with low SAlb and/or high BAs are likely to rapidly develop arsenicosis symptoms.
\end{abstract}

(c) 2014 Elsevier Inc. All rights reserved.

\section{Introduction}

Arsenic, a ubiquitous environmental contaminant, has been classified as a human carcinogenic agent (IARC, 1987; USEPA, 2005; ATSDR, 2007). Chronic exposure to arsenic has threatened and impaired the health of millions of people worldwide (Phan et al., 2013; Fendorf et al., 2010). In general, humans can be exposed to arsenic in several pathways, with oral ingestion being the most common throughout history. Numerous studies have shown that the chronic ingestion of arsenic-rich groundwater leads to the development of hard patches on the palm of the hand and sole of the foot as well as skin lesions, pigmentation, keratosis, and melanosis (Abernathy et al., 2003; Mazumder et al., 2000; Ahsan et al., 2006; Argos et al., 2011). In addition, skin cancer, cancer of the internal organs (urinary bladder, kidney, lung, and liver), diabetes, high blood pressure, and respiratory, circulatory, and reproductive disorders have also been associated with chronic arsenic exposure (Smith et al., 1992; Karagas et al., 2001; WHO, 2008). Arsenicosis symptoms are generally assumed to manifest after decades of consuming arsenic-rich groundwater; however, symptoms were discovered to exist in as short as 3 years of

\footnotetext{
* Corresponding author at: Cambodian Chemical Society, Street 598, Phnom Penh, Cambodia.

E-mail address: kongkeaphan@gmail.com (K. Phan).
}

exposure in rural Cambodia (Sampson et al., 2008). And although some studies have provided evidence that a poor nutritional status may increase an individual's susceptibility to chronic arsenic toxicity (Hsueh et al., 1995; Guha Mazumder et al., 1998; Mitra et al., 2004; Gamble et al., 2005), nutritional functions in arsenic metabolism and toxicity are not fully understood (Milton et al., 2004, 2010). In related studies, a decline in arsenic methylation and an increase in tissue retention of arsenic were observed in animal studies in which rabbits were fed diets containing low methionine, choline, or protein (Vahter and Marafante, 1987). A study on the effects of macronutrient status (body mass index) and micronutrients (plasma folate, vitamin $B_{12}$, zinc, ferritin and selenium) revealed that the metabolism of inorganic arsenic in Bangladeshi women was marginally influenced by their micronutrients status (Li et al., 2008). And providing folic acid supplements to arsenic-exposed Bangladeshi adults with low plasma folate was found to lower their blood arsenic concentrations by decreasing blood monomethylarsonic acid (MMAs V) and increasing urinary dimethylarsinic acid (DMAs V) (Gamble et al., 2007). The assumption of this study was that folic acid supplementation to arsenicexposed population would increase arsenic methylation, a conversion of the ingested inorganic arsenic to an organic one, and facilitate urinary arsenic elimination. Methylation of InAs (III) produces MMAs V and S-adenosyl homocysteine. Hydrolysis of $S$-adenosyl homocysteine provides homocysteine and adenosine. MMAs $\mathrm{V}$ is reduced to monomethylarsonous acid (MMAs III) 
before a subsequent oxidative methylation step yielding DMAs V (Gamble et al., 2007). Previously, in vitro studies have shown that As (III) reacts with human serum albumin (Jiang et al., 2010), thereby suggesting that blood arsenic can bind to the sulfurcontaining amino acid residues of serum albumin among the arsenic-exposed population. However, studies pertaining to factors controlling the development of arsenicosis symptoms are very limited. Here, we investigate relationship of arsenicosis symptoms with total blood arsenic (BAs), and serum albumin (SAlb) of the arsenic-exposed population in the Mekong River basin of Cambodia.

\section{Methods}

\subsection{Field work}

The design of this project was a cross-sectional study which involved 246 participants residing in the arsenic-affected area in the Mekong River basin of Cambodia. Arsenic contamination of groundwater in the Mekong delta of Cambodia was due to arsenic release from river-derived sediments at the near surface and its transport back to the river through underlying aquifer by groundwater flow (Polizzotto et al., 2008). In fact, groundwater and some foodstuffs in Kandal province have been reported highly contaminated with arsenic (Phan et al., 2010, 2013). It is of significant importance to monitor arsenic accumulation in the human body although some residents have stopped drinking groundwater. After our project proposal was approved by the National Ethics Committee for Human Research (Reference no. 114NECHR, 04/08/2011) under the Ministry of Health of the Royal Government of Cambodia and informed consent was obtained, volunteer participants were physically examined for arsenicosis symptoms following the WHO's diagnostic procedure (WHO, 2000) by a trained physician in the Preak Russey Village, Kampong Kong commune, Koh Thom district, Kandal province (Fig. 1). After physical examination, participants were interviewed by a questionnaire whose outcome is summarized in Tables 1 and 2. First, respondents were asked to provide their demographic information including their name, home address, gender and age. Then, they were asked to provide their education levels, occupations and daily incomes. The respondents were also asked to provide their current smoking status and/or tobacco use, they were then asked to provide the source of their drinking water in wet and dry seasons. Groundwater consumption status and option and the location of groundwater were also included in the questionnaire. The amount of water drunk per day, the period of drinking groundwater and the duration of living in the village were also collected. Finally, each participant was asked to sign the written consent after they provided al answers. If a participant manifested one of the arsenic-induced skin lesions such as hyperpigmentation, hyperkeratosis and melanosis $\mathrm{s} /$ he would be identified as the

Table 1

Summary of demographic and socioeconomic information, education level and smoking status of the respondents.

\begin{tabular}{|c|c|c|c|c|c|c|}
\hline & \multicolumn{2}{|c|}{ Asymptomatic } & \multicolumn{2}{|c|}{ Arsenicosis } & \multicolumn{2}{|c|}{ Total } \\
\hline & Count & Total (\%) & Count & Total (\%) & Count & Total (\%) \\
\hline \multicolumn{7}{|l|}{ Gender } \\
\hline Female & 69 & 28.00 & 101 & 41.10 & 170 & 69.10 \\
\hline Male & 46 & 18.70 & 30 & 12.20 & 76 & 30.90 \\
\hline \multicolumn{7}{|l|}{ Age } \\
\hline Age $\leq 12$ years old & 22 & 8.90 & 0 & 0.00 & 22 & 8.90 \\
\hline Age $>12$ years old & 93 & 37.80 & 131 & 53.30 & 224 & 91.10 \\
\hline \multicolumn{7}{|l|}{ Daily income } \\
\hline Earned $\leq$ USD 2.0 & 100 & 40.65 & 108 & 43.90 & 208 & 84.55 \\
\hline Earned $\leq$ USD 5.0 & 14 & 5.69 & 22 & 8.94 & 36 & 14.63 \\
\hline Earned $\leq$ USD 10.0 & 1 & 0.41 & 1 & 0.41 & 2 & 0.81 \\
\hline \multicolumn{7}{|l|}{ Educational level } \\
\hline None & 35 & 14.20 & 69 & 28.00 & 104 & 42.30 \\
\hline$\leq$ Grade 6 & 75 & 30.50 & 54 & 22.00 & 129 & 52.40 \\
\hline$\leq$ Grade 9 & 2 & 0.80 & 8 & 3.30 & 10 & 4.10 \\
\hline$\leq$ Grade 12 & 3 & 1.20 & 0 & 0.00 & 3 & 1.20 \\
\hline \multicolumn{7}{|l|}{ Occupation } \\
\hline Housekeeper & 13 & 5.28 & 25 & 10.16 & 38 & 15.45 \\
\hline Farmer & 61 & 24.80 & 98 & 39.84 & 159 & 64.63 \\
\hline Student & 35 & 14.23 & 2 & 0.81 & 37 & 15.04 \\
\hline Labor worker & 4 & 1.63 & 2 & 0.81 & 6 & 2.44 \\
\hline Fisherman & 2 & 0.81 & 4 & 1.63 & 6 & 2.44 \\
\hline \multicolumn{7}{|l|}{ Smoking status } \\
\hline No & 80 & 32.52 & 80 & 32.52 & 160 & 65.04 \\
\hline Yes, currently & 32 & 13.01 & 48 & 19.51 & 80 & 32.52 \\
\hline Yes, previously & 3 & 1.22 & 3 & 1.22 & 6 & 2.44 \\
\hline \multicolumn{7}{|c|}{ Number of cigarette smoked } \\
\hline Smoke $\leq 5$ per day & 15 & 18.29 & 32 & 39.02 & 47 & 57.32 \\
\hline Smoke $\leq 10$ per day & 5 & 6.10 & 6 & 7.32 & 11 & 13.41 \\
\hline Smoke $\leq 15$ per day & 4 & 4.88 & 2 & 2.44 & 6 & 7.32 \\
\hline Smoke $\leq 20$ per day & 7 & 8.54 & 4 & 4.88 & 11 & 13.41 \\
\hline Smoke $>20$ per day & 2 & 2.44 & 5 & 6.10 & 7 & 8.54 \\
\hline
\end{tabular}

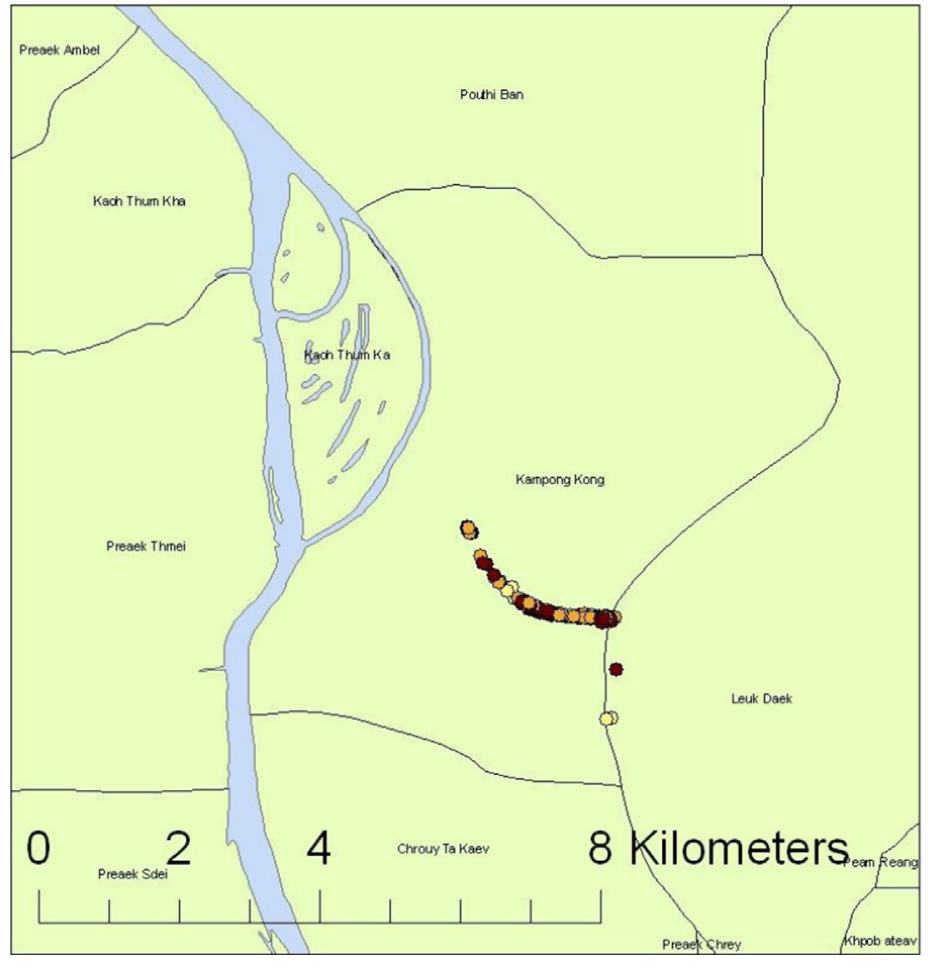

Fig. 1. Map of the study area.

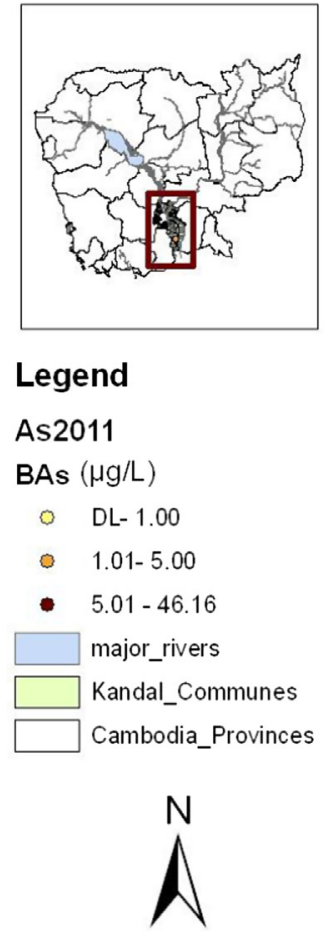

As2011

BAs $(\mu \mathrm{g} / \mathrm{L}$

DL -1.00

1.01- 5.00

$5.01-46.16$

major_rivers

Kandal_Communes

N 
Table 2

Summary of the behavior of water consumption of the respondents.

\begin{tabular}{|c|c|c|c|c|c|c|}
\hline & \multicolumn{2}{|c|}{ Asymptomatic } & \multicolumn{2}{|c|}{ Arsenicosis } & \multicolumn{2}{|l|}{ Total } \\
\hline & Count & $\begin{array}{l}\text { Total } \\
(\%)\end{array}$ & Count & $\begin{array}{l}\text { Total } \\
(\%)\end{array}$ & Count & $\begin{array}{l}\text { Total } \\
(\%)\end{array}$ \\
\hline \multicolumn{7}{|l|}{ Location of tube well } \\
\hline Share with others & 63 & 25.60 & 67 & 27.20 & 130 & 52.80 \\
\hline Well at home & 52 & 21.10 & 64 & 26.00 & 116 & 47.20 \\
\hline \multicolumn{7}{|l|}{ Groundwater consumption } \\
\hline No & 51 & 20.70 & 44 & 17.90 & 95 & 38.60 \\
\hline Yes & 64 & 26.00 & 87 & 35.40 & 151 & 61.40 \\
\hline \multicolumn{7}{|l|}{ Groundwater use option } \\
\hline Bathing & 0 & 0.00 & 2 & 1.30 & 2 & 1.30 \\
\hline Washing dish/cloth & 8 & 5.30 & 5 & 3.30 & 13 & 8.60 \\
\hline Combination & 56 & 37.10 & 80 & 53.00 & 136 & 90.10 \\
\hline \multicolumn{7}{|l|}{ Water used in dry season } \\
\hline Rainwater & 6 & 2.40 & 3 & 1.20 & 9 & 3.70 \\
\hline Piped water & 17 & 6.90 & 12 & 4.90 & 29 & 11.80 \\
\hline Open well/pond & 13 & 5.30 & 18 & 7.30 & 31 & 12.60 \\
\hline $\begin{array}{l}\text { Combined water } \\
\text { sources }\end{array}$ & 79 & 32.10 & 98 & 39.80 & 177 & 72.00 \\
\hline \multicolumn{7}{|l|}{ Water used in wet season } \\
\hline Rainwater & 8 & 3.30 & 7 & 2.80 & 15 & 6.10 \\
\hline Piped water & 2 & 0.80 & 0 & 0.00 & 2 & 0.80 \\
\hline Open well/pond & 2 & 0.80 & 1 & 0.40 & 3 & 1.20 \\
\hline $\begin{array}{l}\text { Combined water } \\
\text { sources }\end{array}$ & 103 & 41.90 & 123 & 50.00 & 226 & 91.90 \\
\hline \multicolumn{7}{|l|}{ Amount of water drunk } \\
\hline Drink $\leq 1.0$ L per day & 36 & 14.60 & 17 & 6.90 & 53 & 21.50 \\
\hline Drink $\leq 1.5$ L per day & 32 & 13.00 & 27 & 11.00 & 59 & 24.00 \\
\hline Drink $\leq 2.0$ L per day & 33 & 13.40 & 64 & 26.00 & 97 & 39.40 \\
\hline Drink $\leq 2.5$ L per day & 2 & 0.80 & 4 & 1.60 & 6 & 2.40 \\
\hline Drink $\leq 3.0$ L per day & 12 & 4.90 & 17 & 6.90 & 29 & 11.80 \\
\hline Drink $>3.0$ L per day & 0 & 0.00 & 2 & 0.80 & 2 & 0.80 \\
\hline
\end{tabular}

arsenicosis patient. Concurrently, spot urine samples were collected from arsenicosis patients $(n=127)$ and asymptomatic villagers $(n=108)$. Spot urine samples were collected from individuals and stored in two different bottles; an acid-cleaned polyethylene bottle and a sterile bottle, both of which were stored in an icebox during fieldwork. Spot urine samples in the acid-cleaned polyethylene bottles were subsequently transferred to a freezer, and stored at $-20{ }^{\circ} \mathrm{C}$ until chemical analyses. Spot urine samples in the sterile bottles were delivered to the Institut Pasteur du Cambodge to measure the urinary creatinine concentrations. Venous blood samples were also collected from the same arsenicosis patients $(n=108)$ and asymptomatic villagers $(n=92)$ in 4 mL EDTA Vacutainers, kept in an icebox and delivered to the Institut Pasteur du Cambodge along with the spot urine samples, in order to measure the serum albumin concentrations. The reminder of the blood samples were frozen at $-20^{\circ} \mathrm{C}$ until they were delivered to Gwangju Institute of Science and Technology (GIST), Republic of Korea, for chemical analyses.

\subsection{Sample preparation and analysis}

Serum albumin (SAlb) and urinary creatinine (UCre) concentrations were determined at the Institut Pasteur du Cambodge using bromocresol green (Roche Diagnostics, COBAS INTEGRA ALB2) and picric acid (Roche Diagnostics, COBAS INTEGRA CREJ2) techniques, respectively. The total arsenic concentration in urine was extracted using a diluted nitric acid solution. In brief, the frozen urine samples were allowed to thaw at room temperature, after which $1 \mathrm{~mL}$ was pipetted into a $15 \mathrm{~mL}$ acid-cleaned polyethylene centrifuge tube. Then, $9 \mathrm{~mL}$ of nitric acid $\left(0.5 \mathrm{~mol} \mathrm{~L}^{-1}\right)$ was added into each tube; the tube was then centrifuged at $3000 \mathrm{rpm}$ for $10 \mathrm{~min}$. The resulting supernatant was filtered $(0.2 \mu \mathrm{m})$ into a fresh tube and stored at $4{ }^{\circ} \mathrm{C}$ until analysis. Concurrently, the total arsenic concentration in blood was measured after digesting with concentrated nitric acid (65\%) and hydrogen peroxide (30\%). In brief, frozen blood samples were allowed to thaw at room temperature, after which $0.20 \mathrm{~mL}$ was pipetted into a $15 \mathrm{~mL}$ acid-cleaned polyethylene centrifuge tube. Then, $0.5 \mathrm{~mL}$ of nitric acid (65\%) was added into each tube, followed by the addition of $1 \mathrm{~mL}$ of hydrogen peroxide (30\%). The mixture was allowed to stand for $15 \mathrm{~min}$ before heating at $100{ }^{\circ} \mathrm{C}$ for $3 \mathrm{~h}$ in a heating block (TAITEC Dry Thermo Unit DTU-2C, Japan). The digestate was then diluted to $10 \mathrm{~mL}$ with 18.2 $\mathrm{M} \Omega$ MilliQ deionized water and filtered $(0.2 \mu \mathrm{m})$ into a fresh tube. All chemical measurements of total arsenic concentration were performed by inductively coupled plasma mass spectrometry (ICP-MS; Agilent 7500 ce, USA).

Spiking of urine and blood was conducted in low $\left(10 \mu \mathrm{g} \mathrm{L}^{-1}\right)$, medium $\left(20 \mu \mathrm{g} \mathrm{L}^{-1}\right)$ and high $\left(50 \mu \mathrm{g} \mathrm{L}^{-1}\right)$ levels. Spiked urine and blood samples were treated in the same manner as the samples in order to verify the accuracy and precision of the extraction and digestion methods. In addition, two replicates of the spot urine and blood samples were extracted and digested to verify the precision and accuracy of the instrumental measurements. The recovery rates (RSD $<10 \%$ ) from the extraction and digestion of urine, blood, and spiked samples were in good agreement with the recommended values (90-110\%).

\subsection{Statistical data analysis}

All statistical data analyses were performed using SPSS for Windows (Version 16.0). Since the data sets were not normally distributed, non-parametric tests were applied. For example, Mann-Whitney $U$ tests were used to verify the differences in urinary arsenic (UAs), UCre, blood arsenic (BAs), and SAlb concentrations between arsenicosis patients and asymptomatic villagers. A binary logistic regression analysis was applied to assess the association between SAlb and BAs for the presence and absence of arsenicosis symptoms. And the strength of correlations between UAs with UCre and BAs with SAlb were determined by Spearman's rho correlation coefficients $\left(r_{\mathrm{s}}\right)$. For all analyses, the significance was considered in circumstances where $p<0.05$.

\section{Results and discussion}

Chemical measurements of the UAs, UCre, BAs, and SAlb concentrations are presented in Table 3. A basic comparison indicates that arsenicosis patients have significantly higher BAs and lower SAlb concentrations than asymptomatic villagers (Mann-Whitney $U$ test, $p<0.05$ ). A significant negative correlation is also found between BAs and SAlb concentrations $\left(r_{\mathrm{s}}(199)=-0.354, p<0.0001\right.$, Fig. 2). Further analyses then revealed that there were no significant differences in the UAs and UCre concentrations between arsenicosis patients and their asymptomatic villagers (Mann-Whitney $U$ test, $\mathrm{p}>0.05$ ), though a significant positive correlation between UAs and UCre concentrations was observed $\left(r_{\mathrm{s}}(237)=0.782, p<0.0001\right)$. These results suggest that the arsenic metabolic pattern of arsenicosis patients is not different from that of asymptomatic villagers. The complexes of arsenic and sulfur-containing amino acid residues of serum albumin are likely to be metabolized and excreted through their urinary systems.

Because both arsenicosis patient and asymptomatic villager lived in the same affected area, the overall levels of their arsenic exposure might not be different. Although they have stopped drinking groundwater, they might get exposed to arsenic through foodstuffs, in particular, rice grown with arsenic-rich groundwater. Given both patient and their asymptomatic villager had equal maximum capability to eliminate arsenic through urination. The higher BAs of patients could be explained by a fact that the more the ingestion the more the toxicity and the more rapidly develop arsenicosis symptoms. Our previous studies revealed that this study population ingested an excess amount of inorganic arsenic from both the groundwater drinking pathway (Phan et al., 2010) and through daily food consumption (Phan et al., 2013). Previous in vitro study reported that there was low binding stability of As (III) to SAlb without specific binding due to access amount of As (III) bound to SAlb in a hydrophobic interaction mechanism after the specific binding site of SAlb is occupied (Jiang et al., 2010). It was suggested that in circumstances in which the sulfurcontaining amino acid residues of serum albumin is saturated with blood arsenic, free blood arsenic may be directly transported and accumulated in susceptible tissues. For example, high arsenic concentrations have been reported in the hair, fingernails, and toenails of the study population (Sampson et al., 2008; Phan et al., 2011; Mazumder et al., 2009). Although the mechanism of arsenicinduced toxicity and carcinogenicity has not been clearly identified there were increased evidences that toxicity and carcinogenicity of arsenic were likely to be closely associated with metabolic processes (ATSDR, 2007). Arsenate is structurally and chemically similar to inorganic phosphate $\left(\mathrm{P}_{i}\right)$ (Nelson and Cox, 2004); it can inhibit the central metabolic pathways and interfere with the 
Table 3

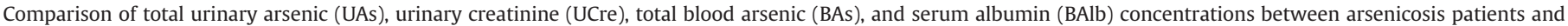
asymptomatic villagers.

\begin{tabular}{|c|c|c|c|c|c|c|}
\hline Variables & Mean \pm SD & Median & Range & Mann-Whitney $U$ & $Z$ & $p$ \\
\hline UAs & & & & 6719.50 & -0.267 & 0.790 \\
\hline Asymptomatic $(n=108)$ & $73.04 \pm 52.24$ & 60.47 & $5.93-312.10$ & & & \\
\hline Arsenicosis $(n=127)$ & $78.74 \pm 69.84$ & 60.22 & $3.76-373.20$ & & & \\
\hline UCre & & & & 6793.50 & -1.231 & 0.218 \\
\hline Asymptomatic $(n=115)$ & $944.08 \pm 621.57$ & 843.00 & $103.00-3097.00$ & & & \\
\hline Arsenicosis $(n=130)$ & $1058.35 \pm 695.07$ & 977.50 & $111.00-4058.00$ & & & \\
\hline SAlb & & & & 3772.00 & -2.932 & 0.003 \\
\hline Asymptomatic $(n=92)$ & $44.28 \pm 3.01$ & 44.30 & $38.00-52.30$ & & & \\
\hline Arsenicosis $(n=108)$ & $42.63 \pm 3.69$ & 43.10 & $25.80-49.70$ & & & \\
\hline BAs & & & & 3595.00 & -3.366 & 0.001 \\
\hline Asymptomatic $(n=92)$ & $6.30 \pm 3.23$ & 5.73 & $0.86-20.94$ & & & \\
\hline Arsenicosis $(n=108)$ & $8.53 \pm 5.97$ & 7.38 & $1.84-46.16$ & & & \\
\hline
\end{tabular}

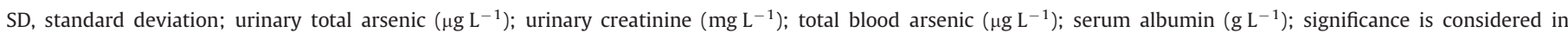
circumstances where $p<0.05$.

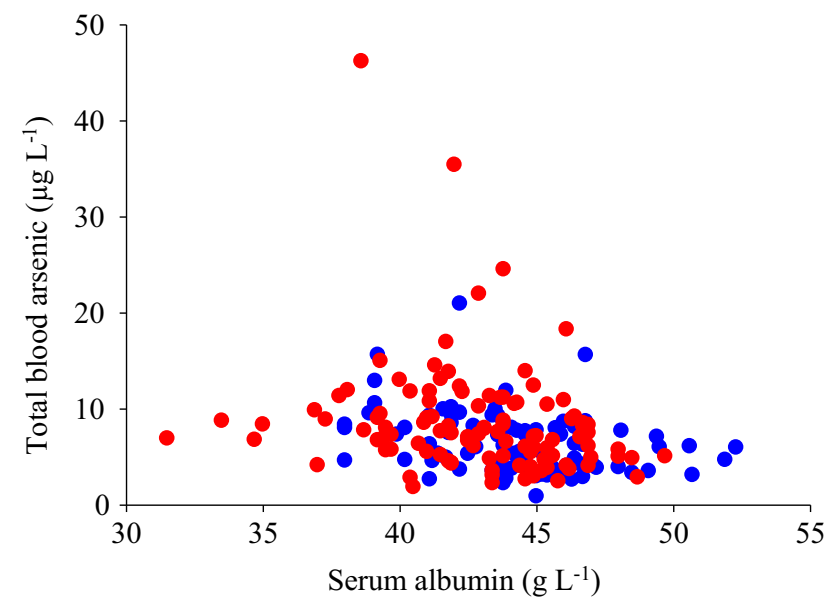

Fig. 2. Correlation between total blood arsenic (BAs) and serum albumin (SAlb) concentrations.

syntheses of DNA by substituting arsenate for analogous phosphate, which then leads to arsenic toxicity and cancer development in the host tissues. The methylation process involved a few intermediates which were more reactive than inorganic arsenic (ATSDR, 2007). Dimethylarsinous acid (DMA III) has been demonstrated to be more toxic than As (III) or As (V) to human hepatocytes, epidermal keratinocytes, and bronchial epithelial cells in the in vitro studies (ATSDR, 2007). A role of the generation of reactive oxygen species in the toxicity of inorganic arsenic has been demonstrated in mechanistic studies of arsenic toxicity whereas MMA III and DMA III are directly genotoxic and much more potent than arsenite at inducing DNA damage (ATSDR, 2007).

We applied a binary logistic regression analysis to assess the association between SAlb and BAs concentrations in both the presence and absence of arsenicosis symptoms in the study populations. As a result, arsenicosis symptoms are 1.764 times (76.4\%) as likely to develop among those who have a SAl$\mathrm{b} \leq 44.3 \mathrm{~g} \mathrm{~L}^{-1}$ (fiftieth percentile of SAlb for asymptomatic villagers) than those with $\mathrm{SAlb}>44.3 \mathrm{~g} \mathrm{~L}^{-1}$ (Odds Ratio $=1.764,95 \%$ $\mathrm{CI}=0.999-3.114)$. Similarly, the arsenicosis symptoms are 2.176 times (117.6\%) as likely to occur among those who have BAs $>5.73 \mu \mathrm{g} \mathrm{L}^{-1}$ (fiftieth percentile of BAs for asymptomatic villagers) than among those who have BAs $\leq 5.73 \mu \mathrm{g} \mathrm{L}^{-1}$ (Odds Ratio $=2.176,95 \% \mathrm{CI}=1.223-3.872$ ). These findings suggest that malnourished people (i.e., low in serum albumin) with high BAs are more likely to develop arsenicosis symptoms. Previous evidence from nutritional studies indicates that a low intake of macronutrients and micronutrients may increase a person's susceptibility to arsenic-caused skin lesions (Mitra et al., 2004; Vahter, 2007; Gamble et al., 2005).

Since the arsenic species in blood and urine samples were not analyzed, arsenic methylation capacity of arsenicosis patients and their asymptomatic villagers could not be clearly defined. On the other hand, the other confounders which might affect the observed relationship were also not included in statistical analysis. Further studies are required to investigate relationship of ingested arsenic and serum albumin and other blood proteins of the exposed population in this region.

\section{Conclusions}

The present study provides additional evidence that a person's nutritional status can be attributed to arsenic toxicity. In addition, since BAs serves as a primary substrate for arsenic metabolism, it is also associated with the development of arsenicosis symptoms. As such, remedial action should be taken into account by decreasing the total blood arsenic concentrations. For example, the rapid development of arsenicosis symptoms could be prevented by reducing the high intake of arsenic-rich groundwater and arsenic-contaminated foods. For this reason, a safe water supply and the development of irrigation systems should be prioritized in arsenic-affected areas. In addition, the development of information, education, and communication (IEC) materials is warranted in order to educate people about health risks from oral arsenic ingestion.

\section{Conflicts of interest}

We have no actual and/or potential conflict of interest to declare.

\section{Acknowledgments}

The authors would like to thank Mrs. Pov Mot for her invaluable field assistance and Institut Pasteur du Cambodge for its support to analyze serum albumin and urinary creatinine. This project is financially supported by UNU \& GIST Joint Programme on Science and Technology for Sustainability in 2011, International Environmental Analysis and Education Center (IEAEC), Gwangju Institute of Science and Technology, Republic of Korea. 


\section{References}

Abernathy, C.O., Thomas, D.J., Calderon, R.L., 2003. Health effects and risk assessment of arsenic. J. Nutr. 133, 1536S-1538S.

Agency for Toxic Substances and Disease Registry (ATSDR), 2007. Toxicological Profile for Arsenic. US Department of Health and Human Services, Public Health Service, Atlanta.

Ahsan, H., Chen, Y., Parvez, F., Zablotska, L., Argos, M., Hussain, I., Momotaj, H., Levy, D. Cheng, Z.Q., Slavkovich, V., van Geen, A., Howe, G.R., Graziano, J.H., 2006. Arsenic exposure from drinking water and risk of premalignant skin lesions in Bangladesh: baseline results from the health effects of arsenic longitudinal study. Am. J. Epidemiol. 163, 1138-1148.

Argos, M. Kalra, T., Pierce, B.L., Chen, Y Parvez, F, Islam, T, Ahmed, A, Hasan, R, Hasan, K., Sarwar, G., Levy, D., Slavkovich, V., Graziano, J.H., Rathouz, P.J., Ahsan, H. 2011. A prospective study of arsenic exposure from drinking water and incidence of skin lesions in Bangladesh. Am. J. Epidemiol. 174, 185-194.

Fendorf, S., Michael, H.A., van Geen, A., 2010. Spatial and temporal variations of groundwater arsenic in South and Southeast Asia. Science 328, 1123-1127.

Gamble, M.V., Liu, X., Ahsan, H., Pilsner, R., Ilievski, V., Slavkovich, V., Parvez, F. Levy, D., Factor-Litvak, P., Graziano, J.H., 2005. Folate, homocysteine, and arsenic metabolism in arsenic-exposed individuals in Bangladesh. Environ. Health Perspect. 113, 1683-1688.

Gamble, M.V., Liu, X., Slavkovich, V., Pisner, J.R., Ilievski, V., Factor-Litvak, P., Levy, D. Alam, S., Islam, M., Parvez, F., Ahsan, H., Graziano, J.H., 2007. Folic acid supplementation lowers blood arsenic. Am. J. Clin. Nutr. 86, 1202-1209.

Guha Mazumder, D.N., Haque, R., Ghosh, N., De, B.K., Santra, A., Chakraborty, D., Smith, A.H., 1998. Arsenic levels in drinking water and the prevalence of skin lesions in West Bengal, India. Int. J. Epidemiol. 27, 871-877.

Hsueh, Y.M., Cheng, G.S., Wu, M.M., Yu, H.S., Kuo, T.L., Chen, C.J., 1995. Multiple risk factors associated with arsenic-induced skin cancer: effects of chronic liver disease and malnutritional status. Br. J. Cancer 71, 109-114.

International Agency for Research on Cancer (IARC), 1987. Monograph on Arsenic and Arsenic Compounds. International Agency for Research on Cancer (IARC) Lyon, FranceS100.

Jiang, H., Ding, J.H., Chang, P., Chen, Z.X., Sun, G.F., 2010. Determination of the interaction of arsenic and human serum albumin by online microdialysis coupled to LC with hydride generation atomic fluorescence spectroscopy. Chromatographia 71, 1075-1079.

Karagas, M.R., Stukel, T.A., Morris, J.S., Tosteson, T.D., Weiss, J.E., Spencer, S.K. Greenberg, E.R., 2001. Skin cancer risk in relation to toenail arsenic concentrations in a US population-based case-control study. Am. J. Epidemiol. 153, 559-565.

Li, L., Ekstrom, E.C., Goessler, W., Lonnerdal, B., Nermell, B., Yunus, M., Rahman, A. El Arifeen, S., Persson, L.A., Vahter, M., 2008. Nutritional status has margina influence on the metabolism of inorganic arsenic in pregnant Bangladeshi women. Environ. Health Perspect. 116, 315-321.

Mazumder, D.N.G., Haque, R., Ghosh, N., De, B.K. Santra, A, Chakraborti, D., Smith, A.H. 2000. Arsenic in drinking water and the prevalence of respiratory effects in West Bengal, India. Int. J. Epidemiol. 29, 1047-1052.
Mazumder, D.N.G., Majumdar, K.K., Santra, S.C., Kol, H., Vicheth, C., 2009. Occurrence of arsenicosis in a rural village of Cambodia. J. Environ. Sci. Health Part a-Toxic/Hazard. Subst. Environ. Eng. 44, 480-487.

Milton, A.H., Hasan, Z., Shahidullah, S.M., Sharmin, S., Jakariya, M.D., Rahman, M., Dear, K., Smith, W., 2004. Association between nutritional status and arsenicosis due to chronic arsenic exposure in Bangladesh. Int. J. Environ. Health Res. 14, 99-108.

Milton, A.H., Shahidullah, S.M., Smith, W., Hossain, K.S., Hasan, Z., Ahmed, K.T., 2010. Association between chronic arsenic exposure and nutritional status among the women of child bearing age: a case-control study in Bangladesh. Int. J. Environ. Res. Public Health 7, 2811-2821.

Mitra, S.R., Mazumder, D.N.G., Basu, A., Block, G., Haque, R., Samanta, S., Ghosh, N., Smith, M.M.H., von Ehrenstein, O.S., Smith, A.H., 2004. Nutritional factors and susceptibility to arsenic-caused skin lesions in West Bengal, India. Environ. Health Perspect. 112, 1104-1109.

Nelson, D.L., Cox, M.M., 2004. Lehninger Principles of Biochemistry. (Ch. 14). 4th ed. WH Freeman, New York.

Phan, K., Sthiannopkao, S., Heng, S., Phan, S., Huoy, L., Wong, M.H., Kim, K.W., 2013. Arsenic contamination in the food chain and its risk assessment of populations residing in the Mekong River basin of Cambodia. J. Hazard. Mater. 262, 1064-1071.

Phan, K., Sthiannopkao, S., Kim, K.W., 2011. Surveillance on chronic arsenic exposure in the Mekong River basin of Cambodia using different biomarkers. Int. J. Hyg. Environ. Health 215, 51-58.

Phan, K., Sthiannopkao, S., Kim, K.W., Wong, M.H., Sao, V., Hashim, J.H., Mohamed Yasin, M.S., Aljunid, S.M., 2010. Health risk assessment of inorganic arsenic intake of Cambodia residents through groundwater drinking pathway. Water Res. 44, 5777-5788.

Polizzotto, M.L., Kocar, B.D., Benner, S.G., Sampson, M., Fendorf, S., 2008. Nearsurface wetland sediments as a source of arsenic release to ground water in Asia. Nature 454, 505-508.

Sampson, M.L., Bostick, B., Chiew, H., Hagan, J.M., Shantz, A., 2008. Arsenicosis in Cambodia: case studies and policy response. Appl. Geochem. 23, 2977-2986.

Smith, A.H., Hopenhayn-Rich, C., Bates, M.N., Goeden, H.M., Hertz-Picciotto, I. Duggan, H.M., Wood, R., Kosnett, M.J., Smith, M.T., 1992. Cancer risks from arsenic in drinking water. Environ. Health Perspect. 97, 259-267.

United States Environmental Protection Agency (USEPA), 2005. Toxicological Review of Ingested Inorganic Arsenic: In Support of Summary Information on the Integrated Risk Information System. United States Environmental Protection Agency (USEPA), Washington.

Vahter, M., Marafante, E., 1987. Effects of low dietary intake of methionine, choline or proteins on the biotransformation of arsenite in the rabbit. Toxicol. Lett. 37, $41-46$

Vahter, M.E., 2007. Interactions between arsenic-induced toxicity and nutrition in early life. J. Nutr. 137, 2798-2804.

World Health Organization (WHO), 2008. 3rd ed.Guideline for Drinking Water Quality: Recommendations, 1. World Health Organization (WHO), Geneva.

World Health Organization (WHO), 2000. United Nations Synthesis Report on Arsenic in Drinking Water. 4. Diagnosis and treatment of chronic arsenic poisoning. World Health Organization, Geneva. 